\title{
Screening of $\beta$-Globin Gene Mutations in Adolescent Schoolgirls in Rural Malang and Sukabumi City, Java Province, Indonesia
}

\author{
Chris Adhiyanto, Yanti Susianti, \\ Nurlaely $M$ Rahmawati, Fase \\ Badriah, Zeti Harriati, Raisha, \\ Ajeng RS Putri, Asry Nurvitasari \\ Faculty of Medicine and Health \\ Sciences \\ UIN Syarif Hidayatullah- Jakarta \\ Indonesia
}

\author{
Umi Fahmida \\ SEAMEO-RECFON, Faculty of \\ Medicine, \\ Universitas Indonesia - Jakarta \\ Indonesia
}

\author{
Annasari Mustafa \\ Polytechnic of Health - Ministry of \\ Health - Malang \\ Indonesia
}

\begin{abstract}
Anemia is one of the major health problems in Indonesia. In general, the condition occurs because of iron deficiency. Another major factor that causes anemia in Indonesia is thalassemia. Usually, the thalassemia patient comes with severe anemia for treatment. Since thalassemia is a genetic disorder, it is necessary to know how to prevent and reduce the incidence. The purpose of this study was to determine the prevalence of thalassemia trait, B-globin gene mutants among adolescent schoolgirls in rural Malang area and Sukabumi City. The early detection of thalassemia will encourage early counseling and treatment. The result of this study found that among 180 adolescent schoolgirls from Malang and Sukabumi, 22 were carrying thalassemic B-globin genes with asymptomatic to mild anemic conditions. Only one of the students had symptoms of intermediate thalassemia. The polymorphism encountered was CD26 in Malang and IVS1nt5 in Sukabumi City.
\end{abstract}

Keywords - thalassemia; anemia in adolescents; Malang; Sukabumi; Indonesia; CD26, and IVS1nt

\section{INTRODUCTION}

Anemia is a major health problem in Indonesia with prevalence of $47.4 \%$ among preschool children, $25.4 \%$ among school-age children, and $41.8 \%$ among pregnant women. The main factor causing anemia in Indonesia is iron deficiency, while other factors are infection, chronic diseases and genetic disorders such as thalassemia [1,2,3]. The prevalence of thalassemia in Indonesia was reported 31\% [4]. Other studies showed the prevalence of thalassemia in certain Indonesian provinces, $4.4 \%$ in West Java [5] and about $8 \%$ in East Java [6]. Among 50 students in Jakarta 6\% carried B-thalassemia Codon 26 (or hemoglobin variant E, HbE) [7]. Thalassemia has a crucial impact not only on the patients, but also on their families and the Government, particularly in terms of providing cost for the treatment.

Beta-globin mutation data in Iran, India, Thailand, or Malaysia are obtained from premarital and family counseling. The data of $\beta$-globin mutation carriers for each country were found to vary, e.g., Iran $0.19 \%$, [8] India 78.17\% [9], Thailand $2.4 \%$ [10], and Malaysia $81.25 \%$ [11]. In Indonesia, the number of thalassemia gene carriers is only acquired from the data of thalassemia patients who visit hospitals for treatment. Comprehensive data on thalassemia trait among the Indonesian population are absent. Hence, there is urgent need of raising public awareness and governmental action in educating the young generation about the importance to alleviate and control the disease in the future.

In our present study, we chose adolescent schoolgirls because they are the candidates to be part of the successor Healthy Indonesia 2025, the health program of the Indonesian government. This study aims to determine the prevalence of thalassemic ß-globin gene carriers among adolescent schoolgirls in rural Malang and Sukabumi City. By providing these data, it is expected that the Government should initiate appropriate programs to better manage thalassemia cases in Indonesia. Furthermore, these data may also encourage the government to educate adolescents with thalassemia minor to prevent the increasing numbers of thalassemia major among the next generation.

\section{A. Subjects}

\section{MATERIALS AND METHODS}

The calculation of sample size to measure the prevalence of thalassemia trait for each district used $80 \%$ of power test, $5 \%$ level of significance, $10 \%$ absolute precision, and $18.8 \%$ anemia prevalence among female age $12-18$ years [12]. Blood samples from 180 adolescent schoolgirls were collected from Malang area and Sukabumi City, Java Island. Three $\mathrm{mL}$ of venous blood were taken from each individual with vacutainer EDTA ${ }^{\circledR}$ for anticoagulant blood collection.

B. Preparing before PCR Sequencing

Complete blood counts (CBC) were performed at Clinical Pathology Laboratory, University Hospital Brawijaya Malang and Bhayangkara Hospital Sukabumi. DNA sequencing was carried out for molecular identification of thalassemia mutations at First Base Molecular Laboratory in Kuala Lumpur, Malaysia. 


\section{PCR Sequencing}

The DNA analysis for $\beta$-globin genes was conducted by PCR using the following primers: forward (50-AGT AGC AAT TTG TAC TGA TGG TAT GG-30; reverse, 50-TTT CCC AAG GTT TGA ACT AGC TCT T-30). The experimental condition for PCR was as following: initial denaturation $\left(95^{\circ} \mathrm{C}, 1 \mathrm{~min}\right)$, followed by 35 cycles of denaturation $\left(95^{\circ} \mathrm{C}, 30\right.$ seconds $)$, annealing $\left(60^{\circ} \mathrm{C}, \quad 30\right.$ seconds), extension $\left(72^{\circ} \mathrm{C}, 30\right.$ seconds) and finally $\left(72^{\circ} \mathrm{C}, 10\right.$ seconds). The PCR product was isolated by agarose gel electrophoresis, $1200 \mathrm{bp}$ amplicon size excised, and purified by QIAquick gel extraction kit (Qiagen, Tokyo, Japan; www.qiagen.com). After dideoxy reaction using BigDye Terminator v1.1 Cycle Sequencing Kit (Applied Biosystems, Tokyo, Japan), it was subjected to DNA sequencing (ABI PRISM3100 Avant Genetic; Applied Biosystems, Tokyo, Japan; customerservice@ lifetech.com) [13].

\section{RESULT}

Genetic evaluation of 180 samples detected more than one polymorphism of B-globin: CD2, T>C; CD26 or $\mathrm{HbE}, \mathrm{G}>\mathrm{A}$; IVS1nt5, G>C; IVS2nt16, G>C and IVS2nt74, T>G. One person had double mutation $\mathrm{Hb}$ variant and $\mathrm{B}$-thalassemia types were CD26 (HbE) and IVS1nt5. For the screening in Malang, 100 samples were investigated based on the results of the CBC for osmotic fragility and analyzed for HbE. Genetic screening using PCR and sequencing, showed that 72 samples had a mutation in CD2, 15 samples in CD26 or HbE, 67 samples in IVS2nt16, 28 samples in IVS2nt74 and one sample in IVS1nt5. The screening 80 samples in Sukabumi based on the results of the $\mathrm{CBC}$ and analysis for hemoglobinopathies showed thalassemia mutations in 35 samples at CD2, in 7 samples at IVS1nt5, in 29 samples at IVS2nt16 and in 14 samples at IVS2nt74.

TABLE 1. DATA OF HEMOGLOBINOPATHY AND GENOTYPE

\begin{tabular}{|c|c|c|c|c|c|c|}
\hline \multirow[b]{2}{*}{ No } & \multirow{2}{*}{$\begin{array}{c}\text { Parameter } \\
\text { CBC }\end{array}$} & \multirow[t]{2}{*}{ Normal Range } & \multicolumn{2}{|c|}{\begin{tabular}{|l|} 
Malang (100 samples) \\
\end{tabular}} & \multicolumn{2}{|c|}{ Sukabumi (80 samples) } \\
\hline & & & $\mathrm{Hb}>12 \mathrm{~g} / \mathrm{dL}$ & $\mathrm{Hb}<12 \mathrm{~g} / \mathrm{dL}$ & $\mathrm{Hb}>12 \mathrm{~g} / \mathrm{dL}$ & $\mathrm{Hb}<12 \mathrm{~g} / \mathrm{dL}$ \\
\hline 1 & Hemoglobin & $12-16 \mathrm{~g} / \mathrm{dL}$ & 13.62 & 10.98 & 13.27 & 10.4 \\
\hline 2 & Red Blood Cell & $4.2-5.4 .10^{\wedge} 6 / \mathrm{L}$ & 4.88 & 4.87 & 4.71 & 4.92 \\
\hline 3 & MCV & $80-97 \mathrm{ft}$ & 83.45 & 72 & 85.94 & 69.35 \\
\hline 4 & MCH & $26.5-33.5 \mathrm{pg}$ & 28.04 & 22.72 & 28.25 & 21.5 \\
\hline 5 & MCHC & $31.5-37 \mathrm{~g} / \mathrm{dL}$ & 33.71 & 31.71 & 32.89 & 30.9 \\
\hline \multirow[t]{2}{*}{6} & RDW-CV & $15 \%$ & 13.44 & 15.34 & 13.63 & 17 \\
\hline & \multicolumn{6}{|c|}{ Thalassemia Calculation test } \\
\hline 1 & Mentzer Index & $>13$ & 17.24 & 15 & 18.33 & 14.4 \\
\hline 2 & Ehsani & $>15$ & 34.3 & 23.11 & 38.43 & 20.15 \\
\hline 3 & RDWI & $>220$ & 229.36 & 227.37 & 250.29 & 239.56 \\
\hline 4 & $S \& L$ & $>1530$ & 1980.25 & 1224.81 & 2097.86 & 1107.5 \\
\hline 5 & Osmotic Fragile Test & Negative & Negative & 1 positive & 2 positive & 5 positive \\
\hline \multirow[t]{2}{*}{6} & Hb E Tahlo Test & Negative & 7 positive & 8 positive & Negative & Negative \\
\hline & \multicolumn{6}{|c|}{ Genetic Sequencing $\beta$-Globin } \\
\hline 1 & $\mathrm{CD} 2, \mathrm{~T}>\mathrm{C}$ & & 48 & 24 & 26 & 9 \\
\hline 2 & $\mathrm{HbE}$ or $\mathrm{CD} 26, \mathrm{G}>\mathrm{A}$ & & 7 & 8 & Non & Non \\
\hline 3 & IVS1nt5, G>C & & Non & 1 & 2 & 5 \\
\hline 4 & IVS2nt16, $\mathrm{G}>\mathrm{C}$ & & 44 & 23 & 25 & 4 \\
\hline \multirow[t]{2}{*}{5} & IVS2nt74,T>G & & 19 & 9 & 9 & 4 \\
\hline & \multicolumn{6}{|c|}{ Genotype Combination } \\
\hline 1 & $\begin{array}{l}\text { CD2,IVS1nt5, IVS2nt16, } \\
\text { IVS2nt74 }\end{array}$ & & Non & Non & Non & 2 \\
\hline 2 & CD2,IVS2nt16, IVS2nt74 & & 18 & 7 & 9 & 2 \\
\hline \multirow[t]{2}{*}{3} & CD2, IVS2nt16 & & 23 & 10 & 14 & 3 \\
\hline & CD2,IVS1nt5 & & Non & Non & Non & 2 \\
\hline 4 & $\mathrm{CD} 2$ & & 4 & 1 & 3 & Non \\
\hline 5 & IVS2nt16 & & Non & 1 & 2 & Non \\
\hline 6 & IVS1nt5 & & Non & Non & 2 & 1 \\
\hline 7 & CD26 & & 4 & 1 & Non & Non \\
\hline 8 & $\mathrm{CD} 2, \mathrm{CD} 26$ & & Non & 1 & Non & Non \\
\hline 9 & CD26, IVS1nt5 & & Non & 1 & Non & Non \\
\hline 10 & CD2,CD26.IVS2nt16 & & 2 & 3 & Non & Non \\
\hline 11 & CD2,CD26,IVS2nt16, IVS2nt74 & & 1 & 2 & Non & Non \\
\hline 12 & \begin{tabular}{|c|} 
Wildtype \\
\end{tabular} & & 16 & 5 & 35 & 5 \\
\hline
\end{tabular}

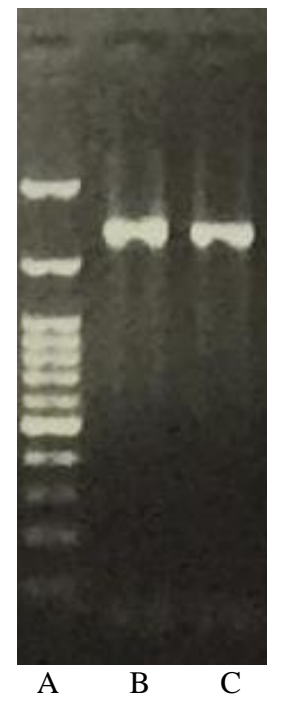

Fig. 1. PCR Result (A: DNA marker $100 \mathrm{bp}$; B and C: PCR product $1200 \mathrm{bp}$ )

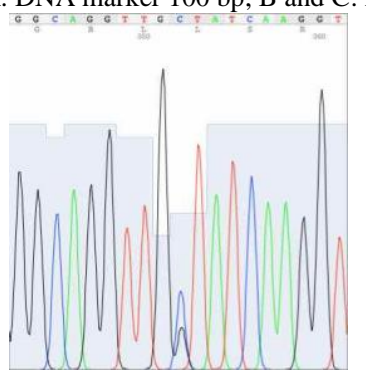

Fig. 2. DNA sequencing for $\beta$-globin mutation IVS1nt5

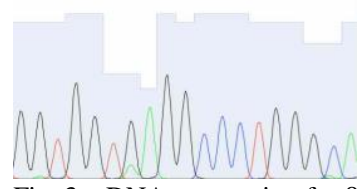

Fig. 3. DNA sequencing for $\beta$-globin mutation CD26

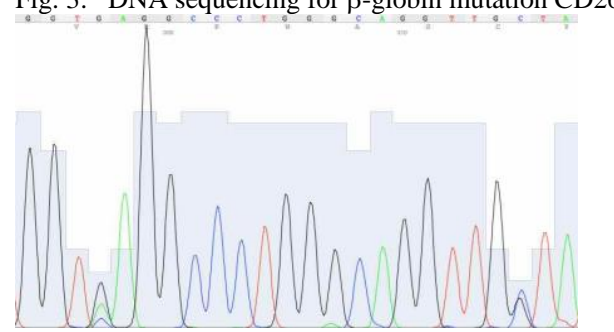

Fig. 4. DNA sequencing for double mutation, CD 26 and IVS1nt5

\section{DISCUSSION}

This study found five types of B-globin gene polymorphism (codon $2 \mathrm{~T}>\mathrm{C}$, Codon 26/HbE G>A, IVS1nt5 $\mathrm{G}>\mathrm{C}$, IVS2nt16 G>C, IVS2nt74 T>G) in adolescent schoolgirls in Malang and Sukabumi City. They had never been diagnosed with hemoglobinopathies according to their medical record. The most common polymorphisms were codon 2, IVS2nt16, and IVS2nt74, followed by codon $26 / \mathrm{HbE}$ and IVS1nt5.

The polymorphism at codon $2 \mathrm{~T}>\mathrm{C}$ in both, homo- or heterozygous forms were found more common of all samples. Some samples had a combination of codon 2 (homo- or heterozygous) with other types of polymorphism showing 
anemic and non-anemic phenotypes. Polymorphism of codon $2 \mathrm{~T}>\mathrm{C}$ converts the code CAT to CAC, both coding for histidine. Therefore, this polymorphism will not cause a pathogenic phenotype. Similar condition had been reported [14].

The polymorphism of B-globin gene at codon $26 \mathrm{G}>\mathrm{A}$, or $\mathrm{HbE}\left(\beta^{+}\right.$-thalassemia) is common in South East Asia. The phenotype of an individual with codon 26 (homo- or heterozygous) is asymptomatic or slightly anemic. This mutation is caused by an alternative-splicing site in the codon and will produce cryptic splicing on mRNA. Cryptic splicing at codon 26 will cause partial truncation of exon 1 and synthesis of unstable of $\beta$-globin. The pathogenic state may be affected by the ratio of HbE mRNA and normal mRNA [1517].

Similar to $\mathrm{HbE}$, the polymorphism of $\beta$-globin gene at IVS1nt5 G>C ( $\beta^{+}$-thalassemia) is another common polymorphism in South East Asia. It will produce a new splicing junction site and reduce splicing efficiency, resulting in an aberrant $\beta$-globin chain formation. Mutations occurring in the splicing consensus area are type $\beta^{+}$, phenotype of mild $\beta$-thalassemia. We found one sample of $\mathrm{Hb}$ level $<9 \mathrm{~g} / \mathrm{dL}$ with the combination of codon $26 \mathrm{G}>\mathrm{A}$ and IVS1nt5. The person did not know about her health condition. The combination of codon $26 \mathrm{G}>\mathrm{A}$ (heterozygous) and IVS2nt5 (heterozygous) has a pathogenic effect with phenotype of intermediate thalassemia, because this mutation (occurring in an exon and intron sequence can activate a splicing site that will produce abnormal mRNA [17].

Another polymorphism which was found in our samples was IVS2nt16. This type is the combination of codon 2 with IVS2nt16; IVS2nt74 can be found in patients with Bthalassemia and healthy people [14]. This polymorphism is a framework of the $\beta$-globin gene $[18,19]$.

Table 1 shows that 7 out of 100 adolescent schoolgirls in Malang area have polymorphism of CD26 without anemic condition, whereas 8 of them have polymorphism of CD26 with anemia and one suffers intermediate thalassemia with $\mathrm{Hb}$ level of $7.5 \mathrm{~g} / \mathrm{dL}$ and double polymorphism of CD26 and IVS1nt5. This condition may be affected by the total amounts and the ratio between $\mathrm{HbE}$ mRNA, IVS1nt5 mRNA, and normal mRNA. In Sukabumi city, we did not find CD26 polymorphism. Two students had polymorphism IVS1nt5 without anemia and 5 students with mild anemia. From Table 1 , we can see that the polymorphism commonly found in Malang area is CD26 or HbE variant (also $\beta+$-thalassemia) and in Sukabumi City it is IVS1nt5 (ß+-thalassemia). This evidence will assist physicians in establishing the diagnosis of individuals suspected having thalassemia in Malang area or Sukabumi City. The knowledge of the geographic and ethnic background will be valuable for diagnostic, counseling and management of B-thalassemia in Indonesia.

Limitations in our study:

Our research intends to investigate the condition of thalassemia in Indonesia, but due to the vast area of Indonesia and insufficient funding sources, the study must be considered preliminary. Nevertheless, it is hoped that it can contribute to describing the individual anemic/thalassemic condition in connection with the background of B-globin gene polymorphism.

\section{CONCLUSION}

The most common polymorphisms found in this study were codon 2, IVS2nt16, and IVS2nt74, followed by codon $26 / \mathrm{HbE}$ and IVS1nt5.

\section{Declaration of interest}

The authors report no conflict of interest. The authors alone are responsible for the content and writing of this article.

\section{Acknowledgment}

The authors are grateful to Prof. Hans-Joachim Freisleben for his help in writing this manuscript. Furthermore, they wish to thank the Ministry of Religion - Indonesia for the support by funding, SEAMEO-RECFON, FKIK UIN Biomolecule Laboratory, and Politeknik Kesehatan Kementerian Kesehatan Malang.

\section{References}

[1] A.E.. Manampiring. In English: Prevalence of anemia and iron sufficiency level in elementary school children in Minaesa village, Wori district, North Minahasa district. Prevalensi anemia dan tingkat kecukupan zat besi pada anak sekolah dasar di desa Minaesa kecamatan Wori kabupaten Minahasa Utara. Thesis Report. Faculty of Medicine University Sam Ratulangi Manado. 2008.

Available from:

http://repo.unsrat.ac.id/252/1/PREVALENSI ANEMIA DAN TINGK AT_KECUKUPAN_ZAT_BESI_PADA_ANAK_SEKOLAH_DASAR. pdf

[2] J. Janus, S.K. Moerchel. Evaluation of anemia in children. Am Fam Physician., vol. 18, no. 12, pp.1462-1467, Jun 2010.

[3] P. A. Wahidayat, Thalassemia in Indonesia. Seminar Talassemia $26-29$ Maret 2013, FKIK UIN Syarif Hidayatullah Jakarta. (Thalassemia Seminar in March $26-29,2013$. Faculty of Medicine and Health Sciences. Universitas Islam Negeri Syarif Hidayatullah Jakarta).

[4] W. Santoso,. In English: Hematologic features of $\beta$-thalassemia heterozygous and $\beta$-thalassemia $\mathrm{Hb}$ E. Gambaran hematologis thalassemia $\beta$-talassemia heterozigot dan thalassemia $\beta$-talassemia $\mathrm{HbE}$. Makalah akhir Program Studi Patologis Klinis PPDS1. The final paper report of thesis the Clinical Pathology Study Program FKUI 1991. Available from: http://lib.ui.ac.id/file?file=pdf/abstrak-82337.pdf

[5] S. Saidin, S.S. Suwardi, A. Murdiana, R. S. Christiani, Martuti, J. Pambudi, Muhilal. In English: Prevalence of anemia and thalassemia in women childbearing age. Prevalensi anemia dan thalassemia karier pada kelompok wanita usia subur. PGM., vol. 24,pp.38-43, 2001.

Available from:

http://ejournal.litbang.depkes.go.id/index.php/pgm/article/view/1504

[6] A.T. Hapsari, L. Rujito. In English: Diagnostic test of blood index and molecular identification of b-thalassemia careers in blood donors in Banyumas - East Java . Uji diagnostic indeks darah dan identifikasi molekuler karier thalassemia beta pada pendonor darah di Banyumas. J Kedok Brawijaya., vol. 28, no.3, pp. 233-237, 2015.

Available from: http://jkb.ub.ac.id/index.php/jkb/article/view/595

[7] Y.R. Dewahrani, C. Adhiyanto, W . Futy, R. Puspitaningrum. Screening of hemoglobin E in students of biology Universitas Negeri Jakarta using Hybri-Probe genotype method. Asian J of Microbiol Biotech Enviro Scien Paper., vol. 17, no.2, pp. 379-385, 2015.

Available from:

http://www.envirobiotechjournals.com/article_abstract.php?aid=5975\&ii $\underline{\mathrm{d}=191 \& \mathrm{jid}=1}$ 
[8] M . Zeinalian, R.F. Nobari, A. Moafi, M. Salehi, M. HashemzadehChalestori. Two decades of pre-marital screening for $\beta$-thalassemia in central Iran. J Community Genet., vol. 4, no. 4, pp. 517-522, Oct 2013.

[9] P.M. Tamhankar, S. Agarwal, V. Arya, R. Kumar, U.R Gupta, S.S. Agarwal. Prevention of homozygous $\beta$-thalassemia bt premarital screening and prenatal diagnosis in India. Prenat Diagn., vo. 29, no. 1 pp. 83-88, Jan 2009.

[10] H. Srivorakun, K. Singha, G. Fucharoen, K. Sanchaisuriya, and S. Fuchsroen. A large cohort of hemoglobin variants in Thailand: molecular epidemiological study and diagnostic consideration. PLOS ONE., vol. 9, no. 9, pp. e108365, Sept 2014.

[11] S. Hassan, R. Ahmad, Z. Zakaria, Z. Zulkafli, and W.Z Abdullah. 2013. Detection of $\beta$-globin gene mutations among $\beta$-thalassemia carriers and patients in Malaysia: application of multiplex amplification refractory mutation system-polymerase chain reaction. Malays J Med Sci., vol. 20, no. 1, pp. 13-20, Jan-Mar 2013.

[12] I.R. Widjaja, F.F. Widjaja, L.A. Santoso, E. Wonggokusuma, Oktaviati. Anemia among children and adolescents in a rural area. Paediatr Indones., vol. 54, no. 2, pp. 88-93, 2014.

[13] A. Chris, Y. Yasuhiro, H. Yukio et al. New b0-thalassemia mutation (codon102, AAC>ATCAC) in coexistence with a heterozygous P4.2 Nippon gene. Hemoglobin., vol. 37, no. 3, pp. 227-240, Apr 2013.
[14] G.N.N. Sultana, R. Begum, H. Akhter, Z., M.A.S. Rahim, G. Chaubey. The complete spectrum of b-thalassemia mutation in Bangladeshi population. Austin Biomark Diagn, vol. 3, no. 1, pp. id1024, Apr 2016.

[15] J.B. Edward Jr, W.B. Brian, L.T. Barry, C. Elaine, C. Thomas, et al. Molecular analysis of the b-thalassemia phenotype associated with inheritance of hemoglobin E ( $\square_{2} \square_{2}{ }^{26 \mathrm{Glu} \rightarrow \text { Lys }}$.J Clin Invest., vol 68, pp. 118-126, 1981.

[16] L.T. Swee. The molecular basis of $\square$-thalassemia. CHS Perspect Med., vol 3, no. 5, pp. a011700, May 2013.

[17] Y. Ghada. El-Kamah and Khalda S. Amr (2015). Thalassemia - From Genotype to Phenotype, Inherited Hemoglobin Disorders, Dr. Anjana Munshi (Ed.)., InTech, DOI: 10.5772/61433. Available from: https://www.intechopen.com/books/inherited-hemoglobindisorders/thalassemia-from-genotype-to-phenotype

[18] G.R. Honig, J.G. Adams. The genetic of the human globin gene loci: formal genetis and gene linkage. In: Honig GR, ed. Human hemoglobin genetics. Wien:Springer-Verlag, 1986:232-233.

[19] C.S. Thom, C.F. Dickson, D.A. Gell, M.J. Weiss. Hemoglobin variants: biochemical properties and clinical correlates. Cold Spring Harb Perspect Med. 2013:3(3):a011858. 